\title{
DĀBĀR IN DIE WYSHEIDSBOEKE
}

\section{DR. J. P. OBERHOLZER}

Die inperking van hierdie oorsig tot die boeke Spreuke, Job en Prediker dien enersyds die grief. Selfs 'n vlugtige oorsig van die aanwending en voorkoms van dābār in die hele Skrif, of slegs in die Ou Testament, sou in 'n tydskrifartikel onmoontlik wees. Andersyds bepaal die inperking die aandag by die wysheidsboeke, en dus by die $\mathrm{Ou}$ Testamentiese wysheid soos dit in hierdie drie boeke neerslag gevind het. Ook die Ou Testamentiese wysheid as sodanig sou 'n veel wyer veld ter sake maak, omdat dit allengs duideliker geword het dat die wysheid 'n veelvuldigheid van verskyningsvorme vertoon wat op een of ander wyse in meeste boeke van die Ou Testament tot gelding kom. Deur ons tot die wysheidsboeke te beperk, het ons egter nog nie so 'n omgrensde gebied betree dat ons die onderwerp in meer as oorsigtelikheid kan benader nie, en moet ons volstaan met die aanduiding van die mees opvallende nuanseringe.

Vir sover dābār met „woord" vertaal moet word, het ons te doen met die gesproke sowel as die geskrewe woord. Die voorkoms van dābār met die werkwoord "skrywe”, ktb, is egter beperk tot die een geval in Pred. 12:10 waar die Prediker se leeren navorsingswerk in verband gebring word met die geskrewe woord. Die wysheid en die skryfkuns is trouens metgeselle van baie eeue, en die tegniese term vir die geleerdestand wat hom besonder op die beoefening van die wysheid toegelê het, getuig daarvan. In sy inleiding op die Spreukeboek behandel prof. B. Gemser die posisie van die "skrywer" in die Ou Nabye Ooste en wys hy op hulle rol as amptenare en onderwysers $\left.{ }^{1}\right)$. Die professionele sófēr en die professionele hākām was dikwels dieselfde persoon.

In die sin van gesproke woord in die omgangstaal, vind ons dābār in die wysheidsboeke slegs enkele kere. Die vriendelike woord in die omgang is dābār tôb. Daarvan word in Spr. 12:25 gesê dat dit die hart opvrolik in teenstelling met bekommernis, wat terneerdrukkend werk. 'n Ander uitdrukking vir die vriendelike, aangename woord is dābār na'îm. Hoewel die gebruik van sulke woorde aangeprys word, kan dit ook verspil word. Daarom waarsku Spr. 23:6-8 teen die aanvaarding van die aangebode gasvryheid van iemand wat „boos van oog" is. Dit is gasvryheid sonder enige egtheid, en vriendelike woorde is daar blote verspilling. Dwarsdeur die wysheidsliteratuur is daar ' $n$ weersin

1) B. Gemser De spreuken van Salomo I, in Tekst en Uitleg, 1929, p. 10, 16. 
aan baie, inhoudlose woorde. Die gebruik van baie woorde is 'n kenmerk van die dwaas. Soos die Prediker dit stel: „Die lippe van 'n dwaas verslind homself", en om dit in die woorde van die New English Bible verder te voer: „He begins by talking nonsense and ends in mischief run mad"! Vgl. naas Pred. 10:12, 13 ook nog Pred. 5:2, 6 en 6:11 en Spr. 10:19. Erger as die dwaas nog, is die onnadenkende, haastige spreker, Spr. 29:20. 'n Woord op sy tyd darenteen, is iets kosbaars en word deur die wysheidsleraars hoog aangeslaan: „Goue appels op versierde silwerborde, so is 'n woord op sy tyd gespreek", Spr. 25:11 - vgl. 15:23. Nie alle woorde wat aangenaam klink, is egter vertroubaar nie, want die woorde van die kwaadstoker kan soos lekkernye na die binneste van die hoorder glip en tog nog dodelik gevaarlik wees, Spr. 18:8 en 26:22. Anders as met die kwaadspreker se heuningdruppende gif, is dit gesteld met die woorde van die openlik vyandige "goddeloses", die rešă 'îm, wat op bloed loer, Spr. 12:6, en met die krenkende woord, debar-céséb, wat die woede van die aangesprokene onmiddellik te voorskyn roep. In hierdie gebruik van dābār klink al iets deur van die gedagte dat die gesproke woord 'n aktiewe werking het wat verdere gebeurtenisse te voorskyn roep. Is die woord eenmaal gespreek, verkry hy 'n onafhanklike geskiedenis wat deur die spreker nie meer gekanselleer kan word nie. Dit kan selfs die geval wees wanneer die spreker by voorbaat maatreëls getref het om sy woorde sonder gevolg te laat wees. Daarom waarsku die Prediker: „Vloek die koning selfs in jou gedagte nie, en vloek in jou slaapkamer nie die ryke nie; want die voëls van die hemel sou die geluid kon wegvoer, en die gevleueldes die woord te kenne gee", Pred. 10:20. Die wysheidsleraar kan egter sy vermaning ook in die ander rigting stuur, omdat hy die disharmonie van menslike verhoudinge ken, in besonder dié van gesagsverhoudinge. Die Prediker sê daarom: „Jy moet ook nie let op al die woorde wat die mense spreek nie, sodat jy nie hoor dat jou dienaar jou vloek nie. Want jou eie hart weet ook van baie gevalle dat jy ander gevloek het", Pred. 7:21. In hierdie geval word dus gepoog om die gesproke woord sy effektiwiteit te ontneem deur dit nie te hoor nie. Die woord roep gebeurtenisse tevoorskyn alleen as dit gehoor word, en die hoorder sodoende tot handeling beweeg. In Spr. 29:19 word verwys na 'n ander geval waarin die woord sonder effek is, nie omdat dit nie gehoor word nie, maar omdat die hoorder weier om tot handeling beweeg te word: „Met woorde laat 'n slaaf hom nie waarsku nie; want hy verstaan dit wel, maar hy steur hom nie daaraan nie". Die onuitgesproke gedagte hierby is dat meer as woorde nodig is om die slaaf te beindruk. Hoewel ons hier met 'n algemene uitspraak te doen het, was sekerlik nie alle 
slawe in verset teen die gesag van hulle here nie. In sy vermaning oor onderwerping aan die gesag van die koning (Pred. 8:2-9) voer die Prediker as grond aan dat dit moet geskied vanweë die šbuat 'élóhîm, 'n uitdrukking wat op uiteenlopende wyse deur kommentatore verklaar word, onder andere as lojaliteitseed onder aanroeping van die Naam van God (Ryder e.a.), 'n eed van God teenoor die koning, vgl. Ps. 89:4, 36 (Herzberg e.a.) of 'n eed aan die koning as sakraal-goddelike figuur (Gemser, Galling, e.a.) $)^{2}$. Dit is hier nie die geleentheid om 'n keuse tussen dié drie moontlikhede te doen nie, want dit gaan vir ons om die bykomstige rede wat die Prediker aanvoer, naamlik dat die woord van die koning magtig is (šiltôn). Die stam slt is Aramees en word deur die Prediker nog gebruik in 2:19; 5:18; 6:2; 7:19; 8:8, 9 en 10:5 in die betekenis van "mag he oor", of in die hif. „beskikking verleen”, of as substantief sallît „maghebber". Hier het ons dus te doen met 'n woord wat effektief is omdat dit die woord van die koning is wat oor die gesagsapparaat beskik om sy uitspraak af te dwing. Hy dra sy gesag nie in homself nie, maar verkry dit vanuit die situasie waarin dit gespreek is.

Die afwesigheid van die gesproke woord darenteen, laat die situasie waarin dit ontbreek, stol tot 'n woordelose reliëf. Die drie vriende van Job word deur sy groot smart daavan weerhou om te spreek. Vir sewe dae en sewe nagte sit hulle swygend by hom in rougewaad. Die swye laat die situasie onversteurd, maar skep tegelyk die spanning van afwagting van die gesproke woord. Hulle spreke begin eers nadat Job met sy klag die opening daartoe geskep het, Job 2:13.

Ook Job se swye ná sy ontmoeting met God kom voort uit die begeerte om die situasie onveranderd te laat. Sy weerhouding van 'n antwoord volg daaruit dat daar nie 'n antwoord moontlik is nie. Die laaste woord is gespreek en die situasie het tot sy finale vorm gekom, Job 39: 37, 38. Dít is ook die opvatting van die gepersonifieerde wysheid, Spr. 1:28: Die eenvoudiges, spotters en dwase wat die woorde van die Wysheid nie in ag neem nie, het hulle laaste kans verspeel. Wanneer húlle die dag roep, sal daar nie antwoord wees nie. Die situasie sal bly soos dit is. Die spreuk „Antwoord 'n dwaas nie na sy sotheid nie, sodat jy ook nie net soos hy word nie" is eweneens gerig op die handhawing van die situasie waarin die wyse en die dwaas duidelike onderskei is.

2) E. T. Ryder, Ecclesiastes, in Peake's Commentary on the Bible, 1962; H. W. Hertzberg, Der Prediger in Kommentar zum Alten Testament, 1963; K. Galling, Prediger Salomo in Handbuch zum Altan Testament, 1940; B. Gemser, Spreuken II, Prediker en Hooglied van Salomo, in Tekst en Uitleg, 1931; Walter Zimmerli, Prediger, in Das Alte Testament Deutsch. 
Die gesproke woord word dus gehoor en nie gehoor nie, gespreek en nie gespreek nie. Vanselfsprekend kry ons in die wysheidsboeke meer te doen met die gesproke woord as die vorm waarin die wysheid oorgedra word, en dan ook meer met die sistematiese wysheidsleer as met die wysheid wat in sy eeuvoudige vorm as spreuk of vermaning in die omgang oorgedra word. Elifas beskryf in Job 4:12-21 op 'n aanskoulike wyse die ontvangs van 'n wysheidsuitspraak oor die algemene sondigheid van die mens, wat geskied in 'n visioen vergesel van 'n oudisie. 'n Woord (dābār) is "steels", op geheimsinnige wyse sonder dat ander dit gehoor het, na hom gebring (jegunnab). Fohrer wys tereg daarop dat met die gebruik van t ${ }^{\circ}$ manâ op bedekte wyse aangedui word dat die openbaring van God self is ${ }^{3}$ ). Die wysheid van Elifas kom dus met die uitspraak op 'n goddelike oorsprong, en is daarmee in ooreensteming met die oud-oosterse wysheid in die algemeen ${ }^{4}$. Hierdie is egter nie die enigste verwysing na die goddelike openbaring in die wysheidsboeke nie. In haar gesagsaanspraak, Spr. 8:22-31, beskryf die Wysheid haarself as die eersteling wat deur die Here berei is en wat dus by Sy skepping van die heelal teenwoordig was. Job vind die antwoord op die probleem van sy situasie in die woorde waarmee die Here hom in 'n teofanie toespreek (Job 38:1; 40:1; 41:7) en Agur vermiaan dat die woorde van God onvervals en sonder toevoeging bewaar moet word as die enigste bron van die ware wysheid, Spr. 30:1-6. Die grootse werke van God in die natuur kan nouliks kennis van God en sy weë verleen, want dit is maar 'n fluisterwoord (šēmés dābār) wat van Hom gehoor word, Job 26:14.

Die dābār as wysheidsleer kom steeds met 'n beroep op die aangesprokene om gehoor te word. Die werkwoord wat vir „hoor" gebruik word, toon dat die aanspraak op die hele persoon gerig word: Naas $\mathrm{Sm}^{\prime}$ is daar 'zn „gehoor gee", nth 'ozén „die oor spits", šjit lēb le "die hart rig op", qšb ,ag slaan op", Hierdie aanspraak om as besondere gesproke woor d behandel te word, berus op die kwaliteit van die wysheid. In die woorde van Pred. 12:11: „Die woorde van die wyse manne is soos prikkels; en soos spykers, diep ingeslaan, is die versamelde spreuke; hulle is deur einge Herder gegee". Die wyse soek na woorde wat tegelyk welgevallig en waarheid is, dibrê-hēfés en dibrê 'émét, Pred. 12:10; uit sy mond kom die woord wat hēn is, aangenaam en skoon tegelyk. Naas die goddelike oorsprong van die wysheid, soos deur Elifas en ook deur Elihu (Job 33:4) gestel, staan die hoë ouderdom daarvan, Spr. 8:22, Job 32:7, maar die aanneembaarheid van die wysheid vir die aangesprokene lê in die

3) G. Fohrer, Das Buch Hiob in Kommentar zum Alten Testament.

4) Vgl. B. Gemser, Spreuken I, p. 8, 14. 
inherente kwaliteit daarvan met betrekking tot die situasie waarin die aangesprokene verkeer. Daarvan hang af of die aangesprokene die vernome dābār deur sy hart sal laat vashou (tmk), Spr. 4:4, en of hy dit sal beskou as die menigte van woorde van 'n loslippige man Job 11:2; as winderige woorde (dibrê-raah) waarvan die beste is dat dit tot 'n einde kom, Job 16:3. Die vergeldingsgedagte was onder andere 'n middel om die gesagsposisie van die wysheid te handhaaf: „Wie die dābār verag moet dit ontgelde; maar hy wat die miswâ vrees, ontvang vergelding" (Spr. 13:13). As wysheidsleer is die dābāar die gesproke woord ('imrâ), die tug (mûsăr), die onderwysing (tôrâ), die kennis (da'at), die gebod (miswâ), die raad ('êsâ), en die teregwysing (tôkahat) van die spreker teenoor die aangesprokene, die verwerping waarvan tot die ongeluk lei. Die wysheid kom dus met die voorneme om te oorreed, met die inherente kwaliteit van die gesproke (en geskrewe) woord as die eintlike grond vir oorreding. In die strydgesprek is die regte woordkeuse derhalwe van die grootste belang, en voor die teregwysing kom dikwels die verontskuldiging, soos in die eerste rede van Elifas: „As 'n mens dit met 'n dābār by jou waag . . . ?"', Job 4:2. Sy eie rede beskryf hy as ,'n woord met sagtheid jou toegespreek" (Job 15:11), maar dié van Job as 'n "pleit met woorde wat nie baat nie" (Job 15:3). 'r. Besondere gewig lē op die woordkeuse wanneer Job hom tot God moet rig: „Hoeveel minder sal ék Hom kan antwoord, sal ek my woorde kan kies teenoor Hom?", Job 9:14.

In die betekenis van „ding” of „saak" kom dābār ook in die wysheidsboeke voor, en verskillende uitdrukkings vir die gesproke woord laat blyk dat daar 'n grensgebied is waarin die gesproke woord en die saak dieselfde is. Om te antwoord is om 'n woord terug te stuur (sûb Hif.), om te spreek is om 'n woord te laat uitgaan (js' Hif.); 'n woord word geglo ('mn, letterlik „,vashou aan"), Pred. 5:1; Spr. 14:15 en 'n boodskap is 'n dābār wat gestuur word (šlh), Spr. 26:6. Ook die gesproke woord is dus objek net soos 'n ding dit is. Die saak wat deur dābār aangedui word, is gewoonlik die nie nadergeduide, nie vas omlynde toestand of kompleks van toestande wat verberg, bedek, nagespeur of verklaar kan word Spr. 25:2; 11:13; 25:2; Pred. 8:1; waaroor geswyg of nie geswyg kan word Job 41:4; wat met kwade gevolge weer opgehaal kan word Spr. 17:9; waarmee 'n mens hom kan inlaat Pred. 8:3 of waarvan 'n mens jou ver kan hou Spr. 30:8; wat 'n aanleidende oorsaak of "wortel" het Job 19:28; wat vermoeiend kan wees vir wie dit wil deurvors en omskrywe Pred. 1:8; as gevolg waarvan iemand kwaad kan ondervind Pred. 8:5. 
In aansluiting by Grether het Procksch die kernbetekenis van dābār gevind in die Arabiese woord dubr "rug”, en gekom tot die betekenis ,rugkant", dit is diepste agtergrond van 'n saak. ${ }^{5}$ ) Ons het in dābār dus te doen met die inhoudelik bepaalde betekenis van 'n woord. „Kein Ding an sich ist dābār, aber jenes Ding hat einen dābār, nämlich seinen Hintergrund und Sinn. Mann versteht dann gut, wie im sprachgebrauch anstelle eines ,Dinges' sein ,Sinn' und „Begriff' eintreten kann, so dasz ein Ding als Ereignis in seinem dābār sein geschichtliches Element hat, weshalb in den debārîm als dem Hintergrund der Dinge die Geschichte einthalten ist". Voorts onderskei Procksch in dābār 'n dianoëtiese en 'n dinamiese element. Wanneer hy van die dianoëtiese element sê dat in die dābār 'n saak kenbaar en aan die denke onderwerp word, sodat wie die dābār van 'n saak begryp het, die saak self begryp het, kom sy onderskeiding tussen die saak en die dābār daarvan egter in die gedrang. Minstens in die wysheidsboeke het ons ondersoek getoon dat die dābār as gesproke woord dikwels die saak self is wat weens sy inherente kwaliteit 'n geskiedenis verky. Daarnaas staan die probleem dat die dābār soos dit gespreek word dikwels die saak eerder verdoesel as kenbaar maak: „Hy kap sy voete af, hy ly onreg wat debărîm stuur deur middel van 'n dwaas" Spr. 26:6. Ook ten opsigte van die dinamiese element van dābār is daar nie te veralgemeen nie. Die dinamiese werking van die dābār hang al te dikwels saam met die situasie waarin dit gespreek word. Elifas se aanspraak op die ontvangs van 'n goddelike openbaring as grond vir die gesagsaanspraak vir sy woorde, maak op Job geen indruk nie. Net so die woorde van die heer teenoor 'n halsstarrige kneg. Die effek. tiwiteit van die woord hang saam met die gesag van die spreker, die gesindheid waarin dit deur die hoorder ontvang word en die situasie waarin dit gespreek word. In Spreuke is dābār dan ook dikwels wenig meer as 'n sinoniem vir 'imrâ. Om hierdie redes kan die skematisering van Procksch en andere slegs met voorbehoud aanvaar word, met die wete dat dit nie in alle gevalle toepaslik is nie.

Die besondere bydrae van die wysheidsboeke ten opsigte van die betekenisomvang van dābār lê in die gestalte wat dit aanneem as wysheidsleer. In die wysheidsleer het ons die oud-oosterse voorloper van wat later wetenskapsbeoefening sou word, en daarin staan dābār nie alleen as die kernbegrip nie, maar tree dit op naas en parallel aan ander begrippe. Volgens Jer. 18:18 is

5) O. Procksch, „Wort Gottes im AT" in Theol. Wörterbuch zum N.T. IV, p. 90. 
die dābār kenmerkend van die nābî, tôrâ van die kóhēn, en 'ēsâ van die hākām. Dat in die wysheidsboeke ook die dābār en die tôrâ vir die wysheid opgeeëis word kom voort uit die strewe van die wysheid, wat hoofsaaklik algemeen-menslike ervaringswysheid is, om te kom tot 'n gesagsposisie. Die Israelitiese wysheid het bowendien met sy klem op die regte verhouding tot God soos uitgedruk in die begrip jir'at JHWH, en met sy oorwinning oor die vergeldingsleer soos in die boek Job, die etiek en die geloof met mekaar verbind, in so 'n mate dat in die uitsprake van Jesus en Paulus die invloed van die wysheidsleer na die vorm, en dikwels ook na die inhoud, onmiskenbaar is. 